\title{
KARAKTERISTIK LIMNOLOGIS, PERKEMBANGAN POPULASI IKAN PATIN SIAM (Pangasionodon hypophthalmus) INTRODUKSI DAN PERIKANAN DI WADUK WONOGIRI, JAWA TENGAH
}

\author{
Endi Setiadi Kartamihardja1), Kunto Purnomo's), Sonny Koeshendrajana ${ }^{3)}$, dan \\ Chairulwan Umar') \\ 1) Peneliti pada Pusat Penelitian Pengelolaan Perikanan dan Konservasi Sumber Daya Ikan, Ancol-Jakarta \\ 2) Peneliti pada Balai Riset Pemulihan Sumber Daya Ikan, Jatiluhur-Purwakarta \\ 3) Peneliti pada Balai Besar Riset Sosial Ekonomi Kelautan dan Perikanan, Petamburan-Jakarta \\ Teregistrasi I tanggal: 8 April 2011; Diterima setelah perbaikan tanggal: 19 April 2011; \\ Disetujui terbit tanggal: 29 April 2011
}

\begin{abstract}
ABSTRAK
Ikan patin siam (Pangasianodon hypophthalmus) diintroduksikan ke Waduk Wonogiri (luas 8.800 ha), Jawa Tengah pada tahun 1999-2002 yang ditujukan untuk mengisi relung ekologis yang kosong dan meningkatkan produksi ikan. Penelitian tentang perubahan karakteristik limnologis waduk, perkembangan dan kontribusi sumber daya ikan patin terhadap hasil tangkapan serta implikasi pengelolaan dan konservasinya telah dilakukan pada tahun 2009. Penelitian ini dilakukan melalui observasi lapang, studi pustaka, dan wawancara. Hasil penelitian menunjukkan bahwa Waduk Wonogiri telah mengalami penyuburan (eutrofikasi). Makanan utama ikan patin adalah plankton, ikan ini dapat memijah secara alami di waduk namun diduga laju rekruitmennya lebih rendah dari laju penangkapannya. Pemanfaatan sumber daya ikan patin siam telah mencapai tingkat optimum yang diindikasikan dengan hasil tangkapan yang stabil pada kisaran 149,6-155,2 ton selama periode tahun 2005-2009. Langkah-langkah pengelolaan yang perlu diterapkan meliputi perlindungan daerah pemijahan dan asuhan ikan patin di muara Sungai Keduwang; perlindungan induk ikan patin di kawasan budi daya keramba jaring apung Cakaran; penebaran benih patin untuk menambah rekruitmen; pengawasan dan penegakkan hukum dalam penggunaan alat tangkap yang merusak dengan melibatkan kelompok masyarakat pengawas; monitoring dan evaluasi hasil tangkapan dengan melibatkan peran serta pedagang pengumpul; dan penguatan kelembagaan pengelola perikanannya.
\end{abstract}

KATAKUNCI: perairan subur, introduksi, manajemen, konservasi, patin siam, Pangasianodon hypopthalmus, Waduk Wonogiri, Jawa Tengah

ABSTRACT: Limnological characteristics, development of introduced the striped catfish (Pangasianodon hypophthalmus) population and fisheries of the Wonogiri Reservoir, Central Java. By: Endi Setiadi Kartamihardja, Kunto Purnomo, Sonny Koeshendrajana, and Chairulwan Umar

Introduction of striped catfish (Pangasianodon hypophthalmus) to Wonogiri Reservoir (a surface water area of 8,800 ha), at Central Java has been conducted in the period 1999-2002. A field observation, desk study, and interview aimed to evaluate limnological characteristics of the reservoir, growth and development of the striped catfish resource, the contribution to total yield and its management 
and conservation implication has been conducted in 2009. Results of the study showed that the Wonogiri Reservoir developed to become an eutrophic waters. The Striped catfish feed on plankton, grew faster and spawn naturally but it is estimated that the recruitment rate was lower than that the exploitation rate. The exploitation of the catfish resource has reached the optimum utilization which is indicated with stabilize the catfish yield at a range of 149.6-155.2 ton in the period of 2005-2009. Management measures which should be implemented include: protecting of the striped catfish spawning and nursery ground at mouth of Keduwang River; protecting the striped catfish brood stock at fish cage culture area at Cakaran; restocking of striped catfish juvenile to increase their recruitment; surveilance and law enforcement of the destructive fishing gear through participation of the society group; monitoring and evaluation of the fish yield through participation of the fish broker; and increasing capacity building of the local fisheries management unit.

KEYWORDS: $\quad$ eutrophic, introduction, management, conservation, striped catfish, Pangasianodon hypopthalmus, Wonogiri Reservoir, Central Java

\section{PENDAHULUAN}

Waduk Wonogiri atau Gajahmungkur di Kabupaten Wonogiri, Jawa Tengah yang diresmikan pembangunannya pada tahun 1981 mempunyai luas 8.800 ha dengan kedalaman rata-rata $6 \mathrm{~m}$. Sebagai perairan waduk yang luas namun dangkal, Waduk Wonogiri termasuk perairan yang mempunyai potensi produksi ikan yang tinggi (Kartamihardja et al., 1988).

Di waduk ini hidup berbagai jenis ikan, baik ikan asli (indigeneous species) antara lain ikan tawes (Barbonymus gonionotus), sogo (Mystus nemurus), dan seren (Cyclocheilichthys apogon) maupun ikan introduksi yang sengaja ditebarkan oleh pemerintah daerah setempat maupun masyarakat seperti ikan nila (Oreochromis niloticus), betutu (Oxyeleotris marmorata) dan patin siam.

Ikan patin siam diintroduksikan ke Waduk Wonogiri dalam periode tahun 19992002 melalui serangkaian penelitian yang dilakukan oleh peneliti dari Pusat Penelitian Pengelolaan Perikanan dan Konservasi Sumber Daya Ikan (dulu Pusat Riset Perikanan Tangkap), Badan Penelitian dan
Pengembangan Kelautan dan Perikanan (Kartamihardja \& Purnomo, 2005). Tujuan introduksi ikan patin tersebut adalah untuk mengisi relung ekologis perairan yang kosong sehingga produksi ikan di perairan tersebut meningkat. Introduksi ikan dilakukan setelah melalui penelitian mengenai aspek limnologi perairan, struktur komunitas ikan, dan relung makanan ikan di waduk tersebut.

Introduksi ikan patin tersebut menunjukkan hasil yang baik, dan sejak tahun 2003 kontribusinya terhadap hasil tangkapan nelayan mulai nampak. Eksploitasi terhadap ikan patin siam dan jenis ikan lainnya di Waduk Wonogiri terus meningkat seiring dengan meningkatnya jumlah nelayan. Jika laju eksploitasi sumber daya ikan patin siam lebih besar dari tingkat rekruitmen alaminya maka seiring dengan berjalannya waktu, populasi ikan patin siam tersebut akan terus menurun sehingga hasil tangkapan per upaya juga akan menurun. Oleh karena itu, untuk mempertahankan hasil tangkapan ikan patin siam diperlukan langkah-langkah pengelolaan dan konservasinya. Berdasarkan atas pertimbangan tersebut maka kajian tentang karakteristik limnologis, perkembangan, 
pengelolaan, dan konservasi sumber daya ikan patin siam di waduk ini perlu dilakukan.

Tujuan penelitian adalah untuk mengevaluasi perubahan karakteristik limnologis waduk, perkembangan dan eksploitasi sumber daya ikan patin siam, serta merumuskan opsi pengelolaan dan konservasi sumber daya ikan patin siam di Waduk Wonogiri. Implementasi dari opsi pengelolaan dan konservasi sumber daya ikan patin tersebut diharapkan dapat menjamin pemanfaatan yang optimal dan sekaligus melestarikan sumber dayanya.

\section{KARAKTERISTIK LIMNOLOGIS WADUK}

Waduk Wonogiri atau Gajahmungkur secara administratif termasuk dalam Kabupaten Wonogri, terletak pada posisi 7웅'-815' LS dan 1104'-11118' BT, ketinggian $140 \mathrm{~m}$ di atas permukaan laut, sekitar 2 km dari Kota Wonogiri (Gambar 1). Waduk ini terbentuk karena pembendungan aliran Bengawan Solo bagian hulu pada tahun 1980 dan mulai diresmikan penggunaannya pada tanggal 17 Nopember 1981.

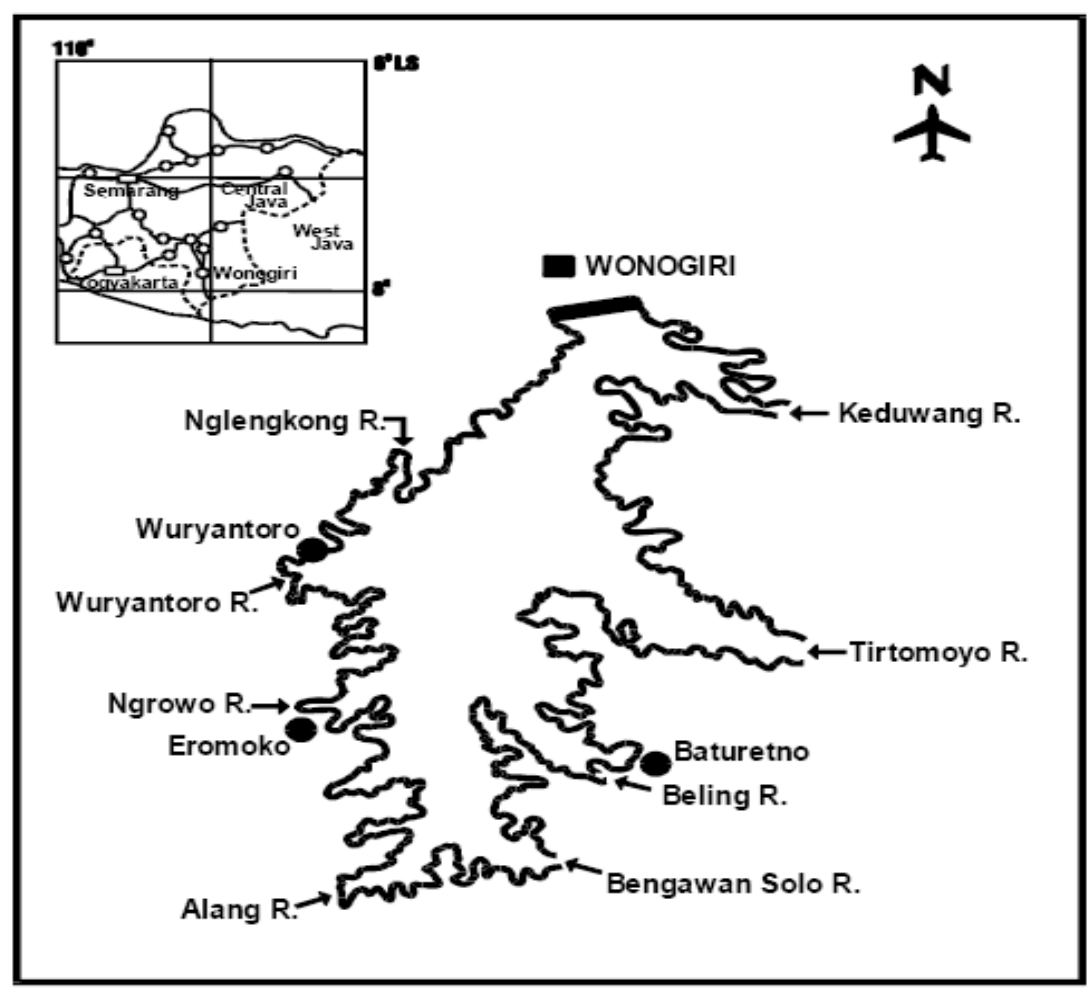

Gambar 1. Peta Waduk Wonogiri di Jawa Tengah.

Figure 1. Map of Wonogiri Reservoir, Central Java.

Selain dari Bengawan Solo, waduk ini menerima limpahan air dari beberapa sungai kecil yang mengalir dalam bentuk struktur bulu burung, yaitu Sungai Tirtomoyo,
Keduwang, Nglengkong, Wuryantoro, Ngrowo, Alang, dan Sungai Beling. Data morfometri Waduk Wonogiri tertera pada Tabel 1 (Suwignyo, 1981). 
Tabel 1. Data morfometri Waduk Wonogiri, Jawa Tengah

Table 1. Morphometric data of Wonogiri Reservoir, Central Java

\begin{tabular}{clc}
\hline No. & \multicolumn{1}{c}{ Parameter/Parameter } & $\begin{array}{c}\text { Ukuran/ } \\
\text { Size }\end{array}$ \\
\hline 1. & Luas genangan maksimum (ha) & 8.800 \\
2. & Luas genangan minimum (ha) & 3.800 \\
3. & Kedalaman maksimum $(\mathrm{m})$ & 35,00 \\
4. & Kedalaman rata-rata $(\mathrm{m})$ & 8,50 \\
5. & Volume air maksimum $\left(\mathrm{km}^{3}\right)$ & 0,75 \\
6. & Panjang garis pantai $\left(\mathrm{km}^{3}\right)$ & 110,0 \\
7. & Panjang maksimum $(\mathrm{km})$ & 13,86 \\
8. & Lebar rata-rata $(\mathrm{km})$ & 6,35 \\
9. & Fluktuasi pasang surut $(\mathrm{m})$ & 11,00 \\
\hline
\end{tabular}

Berdasarkan atas data morfometri Waduk Wonogiri mengindikasikan bahwa waduk tersebut termasuk perairan yang cukup luas, relatif dangkal dan landai dengan banyak teluk serta mempunyai daerah pasang surut yang sangat luas yaitu sekitar 5.000 ha. Proses pasang surut air yang terjadi akan mencuci unsur hara di daerah litoral sehingga menyuburkan perairan waduk. Peningkatan penyuburan perairan waduk juga terjadi karena adanya buangan limbah yang berupa sisa pakan dan kotoran ikan dari budi daya ikan intensif dalam keramba jaring apung.

Parameter fisika-kimiawi dan plankton di Waduk Wonogiri yang diukur pada waktu yang berbeda tertera pada Tabel 2 . Secara umum, kualitas perairan waduk mengalami proses eutrofikasi sejak waduk tersebut dibangun sampai tahun terakhir ini. Kecerahan air mengalami penurunan dari rata-rata $15-30 \mathrm{~cm}$ menjadi $10-20 \mathrm{~cm}$ yang diakibatkan sedimentasi dan limbah dari budi daya ikan dalam keramba jaring apung. Unsur hara yaitu kandungan nitrat dan orto fosfat mengalami peningkatan yang cukup nyata. Unsur-unsur hara tersebut selain dari hasil proses pencucian daerah litoral dan masukkan dari aliran sungai juga buangan dari sisa pakan yang tidak termakan dan kotoran ikan dalam budi daya keramba jaring apung.

Peningkatan kesuburan perairan juga tercermin pada peningkatan kelimpahan fitoplankton dari kisaran 11.140-21.900 sel/ I pada tahun 1988 menjadi 401.079-773.455 sel/l pada tahun 2002, dan meningkat lagi pada tahun 2009 waktu penelitian ini dilakukan, begitu pula dengan peningkatan kelimpahan zooplankton.

Jenis-jenis tumbuhan air yang dijumpai adalah ganggeng (Hydrilla verticillata), kayambang (Salvinea molesta), Ceratophylum demersum, dan rerumputan air (Graminea sp.). Tumbuhan air ini banyak dijumpai di daerah pinggiran (litoral) terutama di Tirtomojo. Di kawasan ini, nampaknya tumbuhan air seperti rerumputan (Graminea sp.) lebih banyak dibandingkan di stasiun lainnya. Di daerah ini perairan relatif dangkal tumbuhan air relatif banyak, sehingga sesuai sebagai habitat berbagai jenis ikan, seperti sebagai daerah asuhan (nursery ground), daerah pemijahan (spawning ground), atau sebagai tempat perlindungan ikan mangsa (prey) dari predator. Kelimpahan tumbuhan air di Waduk Wonogiri tergolong sangat sedikit sehingga tidak merupakan tumbuhan pengganggu atau gulma. Kondisi tersebut sangat sesuai bagi perkembangan dan pertumbuhan populasi ikan. Dalam hal ini, tumbuhan air dapat berfungsi sebagai sumber makanan bagi ikan herbivor, tempat menempelkan telur dan perlindungan bagi anak-anak ikan. 
Tabel 2. Sifat fisika-kimiawi dan biologi perairan Waduk Wonogiri, pada tahun 1988, 2002, dan 2009

Table 2. Physico-chemical and biological characteristics of Wonogiri Reservoir in 1988, 2002, and 2009

\begin{tabular}{|c|c|c|c|}
\hline Parameter/Parameter & Tahun 1988 & Tahun 2002 & Tahun 2009 \\
\hline Suhu air (ํ C) & $27,5-30,5$ & $26,7-29,7$ & $27,5-31,0$ \\
\hline Kecerahan $(\mathrm{cm})$ & $150-200$ & $35-100$ & $35-80$ \\
\hline $\mathrm{pH}$ (unit) & $6,5-8,0$ & $7,0-8,0$ & $6,5-8,0$ \\
\hline Oksigen terlarut (mg/l) & $4.5-6,5$ & $4,2-10,5$ & $4,0-9,5$ \\
\hline Karbondioksida (mg/l) & $1,70-3,40$ & $1,00-3,50$ & $0,0-4,5$ \\
\hline Nitrat (mg/l) & $0,00-0,09$ & $0,00-0,206$ & $0,001-0,324$ \\
\hline Amonium (mg/l) & $0,008-0,088$ & $0,00-0,197$ & ta \\
\hline Orto fosfat (mg/l) & $0,005-0,095$ & $0,00-0,232$ & $0,010-0,322$ \\
\hline Sulfat $(\mathrm{mg} / \mathrm{l})$ & $0,40-1,20$ & ta & ta \\
\hline Bahan organik (mg/l) & $2,46-5,88$ & ta & ta \\
\hline Fitoplankton (sel/l) & $11.140-21.900$ & $401.079-773.455$ & $565.025-885.564$ \\
\hline Zooplankton (ind./l) & $756-1.711$ & 785-1.925 & $987-1976$ \\
\hline Sumber data/Sources & $\begin{array}{l}\text { Kartamihardja et al. } \\
(1988)\end{array}$ & $\begin{array}{l}\text { Kartamihardja et al. } \\
(2002 a)\end{array}$ & $\begin{array}{l}\text { Hasil penelitian ini/This } \\
\text { research }\end{array}$ \\
\hline
\end{tabular}

\section{STATUS PEMANFAATAN PENGELOLAAN PERIKANAN}

Sumber daya ikan yang berkembang pada awal pembendungan adalah jenisjenis ikan asli (indigeneous species) yang berasal dari Bengawan Solo dan sungaisungai lain yang masuk waduk. Jenis ikan yang berkembang adalah jenis ikan yang mampu beradaptasi terhadap lingkungan perairan tergenang, yaitu perairan waduk yang terbentuk.

Jenis-jenis ikan yang hidup di Waduk Wonogiri tertera dalam Tabel 3. Jenis-jenis ikan tersebut didominansi oleh jenis ikan dari famili Cyprinidae yang merupakan ikan sungai (riverine species) dan sedikit sekali jenis ikan yang termasuk kelompok ikan lakustrin (hidup di perairan tergenang).

Dalam rangka meningkatkan stok ikan di waduk ini pemerintah setempat telah menebarkan berbagai jenis ikan tetapi kegiatan tersebut kurang mempertimbangkan aspek perimbangan komposisi jenis ikan serta ketersediaan sumber daya pakan alami yang ada. Beberapa jenis ikan introduksi seperti ikan mas (Cyprinus carpio), nila, patin siam, betutu (Oxyleotris marmorata), dan bawal (Cyprinus carpio) dapat tumbuh dan berkembang biak di waduk. Ikan bawal dan betutu merupakan ikan introduksi yang dilakukan tidak dengan cara kehati-hatian dan oleh karena ke dua jenis ikan ini merupakan ikan predator maka dikhawatirkan akan menjadi kompetitor sehingga mendesak populasi ikan asli. Ikan bawal merupakan ikan asli dari Amazon, Brasil, dan masuk ke Indonesia semula sebagai ikan hias. Kini ikan bawal banyak dipelihara sebagai ikan konsumsi karena pertumbuhannya yang cepat dan mudah beradaptasi dengan lingkungan yang baru. 
Tabel 3. Jenis-jenis ikan yang ditemukan di Waduk Wonogiri, tahun 1988, 2002 dan 2009

Table 3. Fish species found at Wonogiri Reservoir in 1988, 2002, and 2009

\begin{tabular}{clllccc}
\hline No. & $\begin{array}{l}\text { Nama local/ } \\
\text { Local name }\end{array}$ & \multicolumn{1}{c}{$\begin{array}{c}\text { Nama ilmiah/ } \\
\text { Scientific name }\end{array}$} & $\begin{array}{l}\text { Famili/ } \\
\text { Family }\end{array}$ & $\mathbf{1 9 8 8}$ & $\mathbf{2 0 0 2}$ & $\mathbf{2 0 0 9}$ \\
\hline 1. & Tawes & Barbonymus gonionotus & Cyprinidae & ++ & ++ & +++ \\
2. & Bader & Barbodes bramoides & Cyprinidae & ++ & + & + \\
3. & Genggehek & Mystacoleucus marginatus & Cyprinidae & ++ & ++ & + \\
4. & Lukas & Cyclocheilichthys apogon & Cyprinidae & ++ & ++ & ++ \\
5. & Palung & Hampala macrolepidota & Cyprinidae & ++ & + & + \\
6. & Nilem & Osteochilus hasselti & Cyprinidae & + & + & + \\
7. & Sogo & Mystus nemurus & Bagridae & ++ & ++ & ++ \\
8. & Garingan & Mystus nigriceps & Bagridae & ++ & + & + \\
9. & Kutuk & Channa striata & Anabantidae & + & + & + \\
10. & Lempuk & Callichrous bimaculatus & Mastacembelidae & ++ & + & + \\
11. & Sili & Macrognathus aculeatus & Siluridae & + & + & + \\
12. & Mas & Cyprinus carpio & Cyprinidae & - & + & + \\
13. & Nila & Oreochromis niloticus & Cichlidae & - & +++ & +++ \\
14. & Patin Siam & Pangasianodon hypophthalmus & Pangasidae & - & +++ & +++ \\
15. & Betutu & Oxyeleotris marmorata & Oxyeleotridae & - & ++ & ++ \\
16. & Bawal & Colossoma macropomum & Characidae & - & + & + \\
\hline
\end{tabular}

Keterangan/Remarks: - = tidak ditemukan/not found; + = kelimpahan relatif sedikit/relatively rare abundance; $++=$ sedang/medium; +++ = banyak/high .

Sumber data/Sources: Kartamihardja et al. (1989) (nama ilmiah diperbaiki/scientific name corrected); Kartamihardja et al. (2002a); dan hasil penelitian pada tahun 2009/and research results in 2009

Sampai tahun 2008, telah ditebarkan 4.507.000 ekor benih ikan tawes, nila, dan mas oleh Pemerintah Daerah Kabupaten Wonogiri dan Provinsi Jawa Tengah (Dinas Kehewanan, Perikanan dan Kelautan Kabupaten Wonogiri, 2009). Selanjutnya dikatakan bahwa penebaran ikan juga dilakukan oleh masyarakat atau kelompok tani dan nelayan serta PT. Aquafarm Nusantara 721.000 ekor benih ikan tawes, nila, karper (mas), dan patin. Kegiatan penebaran ikan ini nampaknya hanya merupakan kegiatan rutin yang belum secara tepat didasarkan atas pertimbangan ilmiah mengenai potensi sumber daya pakan alami dan kompetisi antar komunitas ikan di perairan waduk tersebut. Penebaran benih ikan nila mungkin tidak perlu dilakukan lagi karena ikan ini dengan cepat dapat tumbuh dan melakukan reproduksi secara alami sehingga dapat mendesak populasi ikan asli. Ikan tawes sebagai ikan herbivora dapat terus dipertimbangkan sebagai ikan tebaran karena ikan ini dapat membantu dalam pengendalian tumbuhan air yang berkembang di perairan waduk dan merupakan ikan asli perairan sungai Indonesia.

Pada tahun 2002, berdasarkan atas produktivitas primernya, Waduk Wonogiri, mempunyai potensi produksi ikan yang berkisar antara $312-455 \mathrm{~kg} / \mathrm{ha} / \mathrm{th}$ atau total potensi produksi ikan antara 2.434-3.549 ton (Kartamihardja et al., 2002a). Lebih lanjut dikatakan bahwa tingkat pemanfaatan sumber daya ikan di Waduk Wonogiri sampai tahun 2008 di bawah potensi produksi ikan lestarinya 1.750 ton. Nilai dugaan potensi hasil tangkapan ini dengan asumsi seluruh fitoplankton yang dihasilkan di perairan waduk dapat dimanfaatkan oleh ikan. Hal ini memberikan indikasi bahwa populasi ikan di Waduk Wonogiri dapat ditingkatkan melalui penebaran ikan dengan jenis pemakan plankton (plankton feeder). 


\section{PERKEMBANGAN POPULASI IKAN PATIN SIAM}

Ikan patin siam yang ditebarkan di Waduk Wonogiri menunjukkan perkembangan yang pesat dengan kisaran pertumbuhan antara 8,7-13,1 g/hari. Pertumbuhan tersebut lebih cepat dari pada pertumbuhan ikan patin di Waduk Jatiluhur yang berkisar antara 5,610,2 g/hari (Kartamihardja et al., 2002b). Hal ini diduga berkaitan erat dengan tingkat kesuburan perairan dan kelimpahan pakan alami yang tersedia. Hasil analisis saluran pencernaan ikan patin yang dilakukan pada tahun 2009 menunjukkan bahwa makanan utamanya fitoplankton dengan makanan tambahan berupa zooplankton dan detritus (Gambar 2a). Kelimpahan plankton yang tinggi di waduk ini ternyata sangat mendukung laju pertumbuhan ikan patin. Makanan ikan patin ini sama dengan hasil penelitian Purnomo (2000) namun berbeda dengan makanan utama ikan patin siam di Waduk Malahayu yang terdiri atas plankton untuk ukuran panjang ikan lebih kecil dari $29,0 \mathrm{~cm}$ dan moluska untuk ukuran yang lebih besar (Purnomo \& Warsa, 2011). Di Sungai Mekong, ikan patin siam bersifat omnivor (Ukkatawewat, 1984) dengan makanan utamanya ikan dan krustase dan makanan tambahannya serasah tumbuhan (Rainboth, 1996). Hal ini hampir sama dengan makanan ikan patin siam di Andra Pradesh, India yang juga termasuk omnivor dengan makanannya terdiri atas krustase, moluska, serasah tumbuhan, dan ikan-ikan kecil (Lakra \& Singh, 2010).

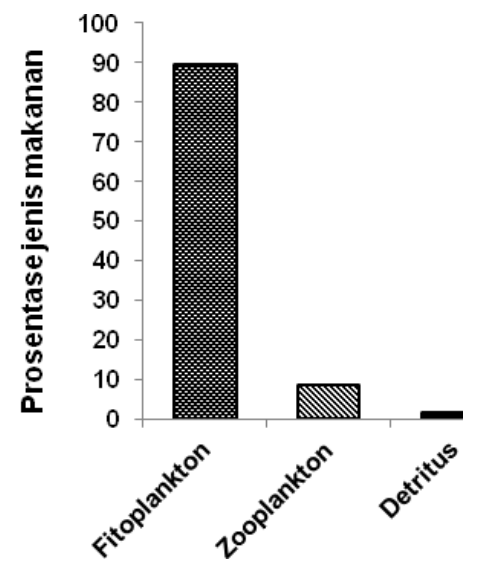

(a)

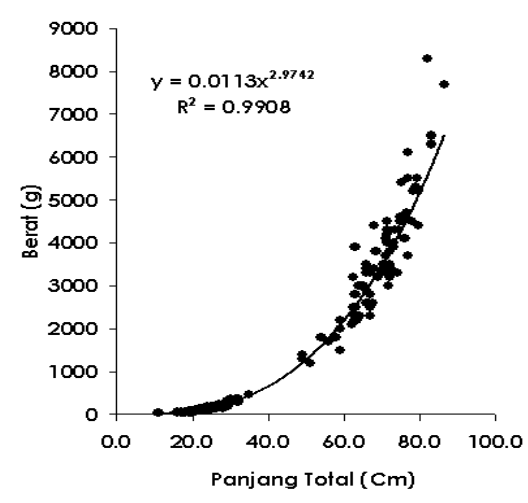

(b)

Gambar 2. Komposisi makanan (a) dan hubungan panjang dan bobot (b) ikan patin di Waduk Wonogiri.

Figure 2. Diets composition (b) and length and weight relationship (b) of striped catfish at Wonogiri Reservoir.

Hubungan panjang dan bobot ikan patin di Waduk Wonogiri mengikuti persamaan $\mathrm{W}=0,0012^{*} \mathrm{~L}^{2,9788}$ seperti pada Gambar $2 \mathrm{~b}$ (Purnomo et al., 2003). Hubungan panjang dan bobot ini selaras dengan hubungan panjang dan bobot ikan patin yang dikemukakan dalam FishBase yang mengikuti persamaan $\mathrm{W}=0,0152^{*} \mathrm{~L}^{3,000}$.

Pada Gambar 2b tersebut terlihat bahwa ikan patin hasil tebaran dapat tumbuh mencapai ukuran $8,7 \mathrm{~kg}$, sedangkan ikan 
patin bertanda terbesar yang tertangkap kembali di Waduk Jatiluhur mencapai 7,6 kg/ekor (Kartamihardja et al., 2002b). Pada tahun 2001, di Waduk Srinakarin, Thailand ikan patin terbesar yang pernah tertangkap 24,0 kg sedangkan di Danau Shadow tertangkap ikan patin 25,0 kg (Sayeed et al., 2008).

Kartamihardja et al. (2002a) mengatakan bahwa distribusi ikan patin siam di Waduk Wonogiri cukup jauh di mana tiga hari setelah penebaran ikan tersebut di daerah Cakaran ada yang sudah mencapai daerah hulu yaitu di Baturetno dan di daerah Watupecah (dekat bendungan). Ikan patin berukuran besar pada umumnya menyebar di bagian tengah dan hilir waduk (dekat bendungan) sedangkan yang berukuran relatif kecil menyebar di daerah hulu waduk (Muara Bengawan Solo). Migrasi benih ikan patin siam tersebut erat hubungannya dengan keperluan pencarian makanan atau menghindari predator atau penyebab lainnya.

Ikan patin siam yang ditebarkan pada tahun 2001, ternyata dapat memijah di daerah hulu waduk, terutama di Sungai Keduwang bagian hilir yang masuk waduk. Hal ini terlihat dari banyak tertangkapnya benih ikan patin ukuran 10-15 cm dengan bobot antara 15-25 g pada bulan Mei (Kartamihardja \& Purnomo, 2005). Benih ikan patin ukuran tersebut diperkirakan merupakan hasil pemijahan sekitar 2-3 bulan yang lalu atau sekitar bulan Januari sampai Pebruari. Di habitat aslinya di Sungai Mekong, ikan patin siam migrasi ke bagian hulu sungai untuk memijah pada bulan Mei sampai Juli dan pada waktu permukaan air sungai surut, anak-anaknya migrasi ke bagian hilir sungai pada bulan September sampai Desember (Hill \& Hill, 1994). Habitat induk ikan patin siam di Sungai Mekong adalah di bagian sungai yang dalam dan habitat pemijahannya di alur sungai yang berbatu sedangkan telurnya menempel pada tumbuhan reofilik (Zalinge et al., 2002). Keberhasilan pemijahan ikan patin siam secara alami di perairan Waduk Wonogiri merupakan kasus yang pertama terjadi di perairan umum Indonesia sejak ikan patin tersebut diintroduksikan pada tahun 1976 sebagai ikan budi daya. Kemampuan berkembang biak secara alami tersebut akan berdampak terhadap rekruitmennya sehingga pada masa yang akan datang, jika laju rekruitmennya memadai tidak diperlukan lagi penebaran ulang. Analisis fekunditas ikan patin pada ukuran panjang total antara 67,0-82,7 cm dengan bobot antara 3,0-5,5 kg berkisar antara 271.700-1.177.250 butir (Adjie et al., 2005). Hal ini juga menunjukkan bahwa ikan patin pada ukuran panjang $67,0 \mathrm{~cm}$ dengan bobot $3,0 \mathrm{~kg}$ sudah mulai matang kelamin. Di Sungai Mekong, ikan patin siam mulai matang gonad pada umur lebih dari tiga tahun dan fekunditasnya meningkat secara dramatis dari sekitar 30.000 telur pada ukuran ikan $5 \mathrm{~kg}$ menjadi 1.000 .000 butir telur pada ikan patin siam ukuran $10 \mathrm{~kg}$ (Zalinge et al., 2002).

\section{PEMANFAATAN DAN PENGELOLAAN SUMBER DAYA IKAN PATIN}

Introduksi ikan patin di Waduk Wonogiri telah berdampak positif terhadap hasil tangkapan nelayan. Pada tahun 2004 hasil tangkapan patin siam berada pada urutan ketujuh terbesar (Gambar 3) dengan nilai total hasil tangkapan pada tahun 2004 sebesar Rp.785,5 juta (Kartamihardja \& Purnomo, 2005). Pada tahun 2008, hasil tangkapan ikan patin berada pada urutan keempat setelah ikan nila dengan jumlah hasil tangkapan $155.226 \mathrm{~kg}$ atau senilai Rp.1.319,421 juta (Dinas Kehewanan, Perikanan dan Kelautan Kabupaten Wonogiri, 2009). 
Tahun 2004

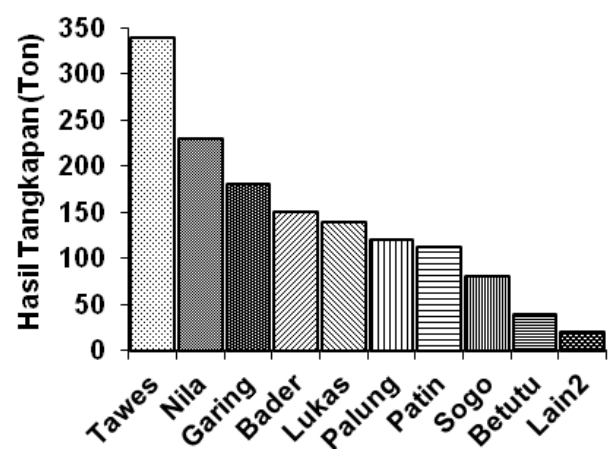

Tahun 2008

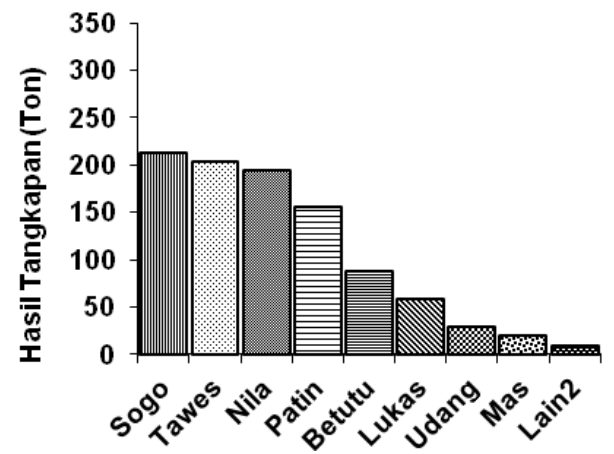

Gambar 3. Komposisi hasil tangkapan ikan yang dominan di Waduk Wonogiri, tahun 2004 dan 2008.

Figure 3. $\quad$ Catch composition of dominant fish species at Wonogiri Reservoir in 2004 and 2008.

Komposisi hasil tangkapan ikan dari tahun 2004-2008 mengalami pergeseran, ikan sogo yang tadinya berada pada peringkat kedelapan bergeser menjadi peringkat pertama. Komposisi hasil tangkapan ikan patin di Waduk Wonogiri menunjukkan peningkatan dari $0,8 \%$ pada tahun 2001 (Kartamihardja et al., 2002b) menjadi $7,8 \%$ pada tahun 2004 dan meningkat secara tajam sehingga pada tahun 2008 menjadi $28,0 \%$ dari total hasil tangkapan 553 ton (Gambar 3).

Sejak tahun 2005, hasil tangkapan ikan patin berfluktuasi pada kisaran rata-rata 155 ton/tahun (Gambar 4). Hal ini mengindikasikan bahwa pemanfaatan sumber daya ikan patin telah mencapai tingkat pemanfaatan penuh atau pemanfaatan sumber daya makanan dan habitat oleh ikan patin telah mendekati daya dukungnya. Kemungkinan yang lain adalah laju rekruitmen sumber daya ikan patin sebanding dengan laju pemanfaatannya. Apabila kemungkinan ini yang terjadi dan berdasarkan atas ketersediaan sumber daya pakan alami yang berupa plankton yang cukup tinggi maka peningkatan stok ikan patin dapat ditingkatkan dengan cara menambah laju rekruitmennya melalui penebaran benih. Pada uraian sebelumnya telah disebutkan bahwa potensi produksi ikan lestari Waduk Wonogiri dapat mencapai 1.750 ton/tahun sedangkan hasil tangkapan ikan yang telah dicapai sekitar 970 ton, oleh karena itu peningkatan produksi ikan di waduk ini dapat ditingkatkan. Penebaran ikan patin siam dan jenis ikan pemakan plankton lainnya dapat meningkatkan produksi ikan di perairan ini. 
Gambar 4. Hasil tangkapan ikan patin di Waduk Wonogiri periode tahun 2001-2009.

Figure 4. The striped catfish caught from Wonogiri Reservoir in 2001-2009.

Berdasarkan atas data dan informasi tentang aspek biologi ikan patin di Waduk Wonogiri, status pemanfaatan populasi ikan patin dan perikanannya, maka untuk menjamin kelestarian hasil tangkapan dan sumber daya ikan patin siam di Waduk Wonogiri diperlukan penerapan langkahlangkah pengelolaan. Beberapa langkah pengelolaan dan konservasi sumber daya ikan patin siam yang perlu dilakukan meliputi:

1. Penetapan kawasan suaka ikan patin siam. Kawasan suaka atau konservasi ini berfungsi untuk melindungi habitat pemijahan, asuhan, dan pembesaran ikan patin yang berlokasi di muara Sungai Keduwang. Pengelolaan dan pengawasan kawasan suaka ini setelah disepakati oleh seluruh kelompok nelayan maka perlu diikuti dengan penetapan peraturannya. Pada tahap awal, peraturan tersebut dapat dibuat berdasarkan atas kesepakatan masyarakat nelayan untuk kemudian pada tahap berikutnya ditetapkan berdasarkan atas peraturan daerah. Tahapan pembuatan peraturan ini perlu dilakukan karena pembuatan peraturan daerah akan membutuhkan waktu yang cukup lama.

2. Penetapan daerah perlindungan induk ikan patin siam. Induk ikan patin siam banyak terkumpul dii daerah budi daya ikan dalam keramba jaring apung di Cakaran. Induk ikan patin siam yang banyak berada di lokasi ini dapat memanfaatkan sisa pakan yang lolos ke luar dari keramba jaring apung. Di samping itu, kesepakatan dan komitmen yang dibangun antara nelayan dan pembudidaya ikan keramba jaring apung akan menghasilkan keamanan budi daya karena tidak ada nelayan yang menangkap ikan di lokasi tersebut dan stok induk ikan patin siam terlindungi untuk melakukan pemijahan pada waktunya.

3. Penebaran benih ikan patin siam untuk menambah rekruitmen alami. Pepambahan laju rekruitmen ikan patin

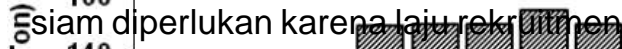

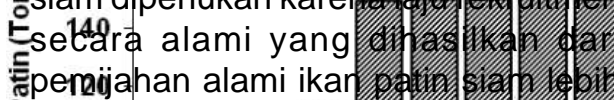

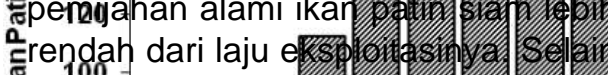
气̈kan 100 atin siam, Inilasomas, dan ta

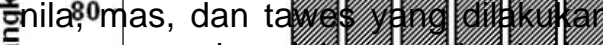

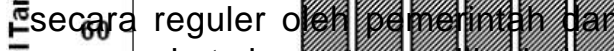
"̄masyarakat dap Iseh4ngga \$y habitat dimanffert,

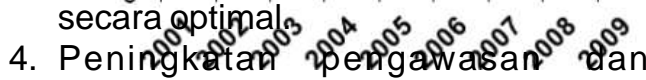
penegakkan hukum. Selama ini praktek penangkapan yang merusak sumber daya ikan seperti penggunaan alat tangkap branjang (lift net) dengan ukuran mata jaring yang kecil sering terjadi terutama dilakukan oleh nelayan pendatang yang tidak masuk sebagai anggota kelompok. Pengawasan dapat melibatkan kelompok masyarakat 
pengawas yang telah ada. Untuk keperluan tersebut, penyediaan sarana pengawasan perlu difasilitasi oleh Pemerintah Daerah Kabupaten Wonogiri.

5. Penguatan kelembagaan pengelolaan. Kelompok nelayan dan kelompok masyarakat lainnya seperti pedagang dan pengolah ikan perlu ditingkatkan kapasitasnya melalui pelatihan yang berkaitan dengan teknik-teknik pengelolaan dan konservasi sumber daya ikan serta pengolahan hasilnya. Hal ini penting dilakukan agar seluruh nelayan dan masyarakat lainnya mempunyai presepsi dan komitmen serta kemampuan yang sama dalam mengelola sumber daya perikanan di Waduk Wonogiri.

6. Monitoring hasil tangkapan ikan. Monitoring hasil tangkapan ikan dapat dilakukan dengan melibatkan peran serta pedagang ikan. Pencatatan hasil tangkapan ikan harian agar dilakukan di tempat pendaratan ikan yang tersedia yaitu di Kecamatan Wonogiri, Wuryantoro, Eromoko, Nguntorongadi dan Baturetno. Data hasil monitoring ini sangat penting untuk mengevaluasi efektivitas pengelolaan dan konservasi sumber daya ikan patin siam yang telah diterapkan. Dengan demikian akan terbentuk rejim pengelolaan perikanan bersama secara adaptif (adaptive comanagement).

Langkah-langkah pengelolaan dan konservasi sumber daya ikan patin siam ini perlu dituangkan dalam rencana pengelolaan untuk kemudian disosialisasikan kepada seluruh pemangku kepentingan. Oleh karena masalah pengelolaan dan konservasi sumber daya ikan patin tersebut belum tertuang dalam Peraturan Daerah Kabupaten Wonogiri Nomor 9 Tahun 2003 tentang retribusi izin usaha perikanan di perairan Waduk Gajah Mungkur, Wonogiri maka adendum terhadap Peraturan Daerah tersebut perlu dilakukan.

\section{STATUS PEMANFAATAN SUMBER DAYA IKAN DAN PENGELOLAAN PERIKANAN}

Kegiatan perikanan tangkap di Waduk Wonogiri dimulai sejak waduk tersebut selesai dibangun pada tahun 1981 yang dilakukan oleh masyarakat di sekitar waduk. Hasil tangkapan ikan dari Waduk Wonogiri tergolong tinggi jika dibandingkan dengan rata-rata produksi ikan yang dihasilkan dari perairan waduk di Indonesia. Selama periode tahun 2005-2008, hasil tangkapan ikan berkisar antara 748,237-916,030 ton (Dinas Kehewanan, Perikanan, dan Kelautan Kabupaten Wonogiri, 2009) dan pada tahun 2009 sampai kuartal ketiga telah dicapai produksi 668,947 ton dan berdasarkan atas rata-rata hasil tangkapan selama tiga kuartal diperkirakan akan mencapai lebih dari 900 ton (Gambar 5).

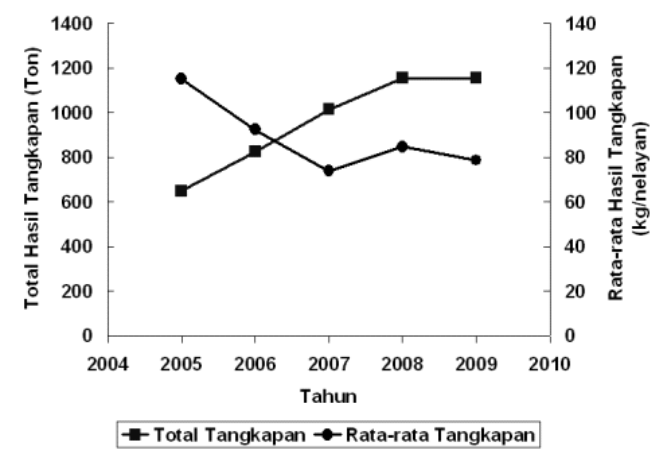

Gambar 5. Total dan rata-rata hasil tangkapan ikan di Waduk Wonogiri dalam periode tahun 2005-2009.

Figure 5. Total and average of fish caught at Wonogiri Reservoir in 2005-2009. 
Jumlah nelayan yang beroperasi dari tahun ke tahun terus meningkat. Pada tahun 2005, jumlah nelayan yang beroperasi di Waduk Wonogiri tercatat 650 orang dan meningkat menjadi 1.156 orang pada tahun 2008 (Dinas Kehewanan, Perikanan, dan Kelautan Kabupaten Wonogiri, 2009). Jumlah kelompok nelayan juga meningkat tajam, pada tahun 2005 tercatat hanya 15 kelompok nelayan dan berkembang menjadi 43 kelompok nelayan pada tahun 2008. Organisasi nelayan di waduk ini secara umum sudah cukup baik, hal ini berkat pembinaan dari Dinas Kehewanan, Perikanan, dan Kelautan setempat. Secara rutin, setiap bulan tiap kelompok nelayan mengadakan pertemuan kelompok dan setiap tiga bulanan tiap ketua kelompok mengadakan pertemuan dengan Dinas Kehewanan, Perikanan, dan Kelautan di Wonogiri guna membahas masalah yang dihadapi tiap kelompok dan menerima arahan yang selanjutnya disampaikan kepada anggota tiap kelompok.

Alat tangkap ikan yang banyak digunakan oleh nelayan di Waduk Wonogiri adalah jaring insang, pancing rawai, jala, bubu, dan pancing. Nelayan, terutama di daerah Baturetno mulai banyak menggunakan branjang (lift net). Alat tangkap branjang banyak ditentang masyarakat karena menggunakan ukuran mata jaring kecil sehingga dapat menghabiskan sumber daya ikan, terutama ikan-ikan kecil atau benih. Bubu khusus digunakan untuk menangkap udang.

Harga ikan hasil tangkapan di Waduk Wonogiri bervariasi tergatung dari jenis ikannya. Pada tahun 2009, harga ikan sogo berkisar antara Rp.7.000-8.000; bader Rp.6.000; betutu (ukuran 400-1.000 g/ekor) Rp.45.000, ukuran 350 g/ekor, Rp.30.000, ukuran 300 g/ekor, Rp.25.000 dan ukuran 150 g/ekor, Rp.15.000; ikan lukas, nila, dan tawes berkisar antara Rp.6.000-7.000.
Harga ikan patin mencapai Rp.8.500/kg sehingga merupakan jenis ikan hasil tangkapan yang mempunyai harga jual paling tinggi setelah ikan betutu.

Pada tahun 2003, setelah diadakan pertemuan antara pihak dinas setempat, kelompok nelayan dan peneliti Pusat Penelitian Pengelolaan Perikanan dan Konservasi Sumber Daya Ikan telah dicapai kesepakatan bahwa pihak nelayan menyisihkan sebagian uang hasil tangkapannya guna disumbangkan sebagai dana kelestarian sumber daya ikan. Pada waktu itu, jumlah yang disepakati adalah Rp.50.000 per kelompok nelayan dan dalam perkembangannya mengalami peningkatan menjadi Rp. 150.000 per kelompok nelayan. Kesepakatan tersebut telah dituangkan dalam bentuk Surat Keputusan Kepala Dinas yang selanjutnya ditindaklanjuti menjadi Peraturan Daerah Kabupaten Wonogiri Nomor 9 Tahun 2003 tentang retribusi izin usaha perikanan di perairan Waduk Gajah Mungkur Wonogiri.

Secara umum, pengelolaan perikanan yang telah dilakukan di Waduk Wonogiri meliputi pembagian zonasi waduk, penebaran ikan, dan regulasi perikanan serta pembentukkan kelembagaan perikanan. Langkah-langkah pengelolaan ini telah didukung dengan Peraturan Daerah Kabupaten Wonogiri meskipun dalam implementasinya mengalami kendala, terutama dalam masalah penegakkan hukumnya.

Pendekatan pengelolaan bersama (comanagement) semakin sering digunakan untuk pengelolaan sumber daya alam. Pengelolaan bersama merupakan suatu pengaturan kemitraan dalam tanggung jawab dan kewenangan antara pelaku kunci atau pemangku kepentingan dalam pengelolaan sumber daya alam yaitu masyarakat lokal dan pemerintah. 
Pengelolaan bersama menggunakan kemampuan dan minat nelayan dan pembudidaya ikan tingkat lokal, dan masyarakatnya yang dikombinasikan dengan kemampuan pemerintah dalam menyediakan perangkat hukum yang memungkinkan atau bantuan lainnya. Hubungan ideal kemitraan tersebut tergantung pada kapasitas berbagai pelaku lokal dan sifat alami sumber daya alam yang dikelola (Pomeroy et al., 2001).

\section{KESIMPULAN}

Introduksi ikan patin siam di Waduk Wonogiri telah berhasil baik dan berdampak positif terhadap peningkatan produksi ikan dan taraf hidup nelayan setempat. Ikan patin siam yang ditebarkan dapat tumbuh dan berkembang-biak dengan baik dalam memanfaatkan sumber daya makanan alami yang tersedia dan mengisi habitat pemijahannya. Untuk menjamin kelestarian sumber daya dan hasil tangkapan ikan patin siam perlu dilakukan langkah-langkah pengelolaan dan konservasi sumber daya ikan patin siam yang meliputi penetapan suaka perikanan, pengendalian alat tangkap yang merusak (seperti branjang), pengawasan dengan melibatkan kelompok nelayan, penguatan kelembagaan pengelola perikanannya, dan monitoring hasil tangkapan.

\section{DAFTAR PUSTAKA}

Adjie, S., A. D. Utomo, N. Muflikhah, \& Krismono. 2005. Studi biologi ikan jambal siam (Pangasius hypophthalmus) di Bengawan Solo bagian hulu. Prosiding Forum Perairan Umum Indonesia III. 7584.

Dinas Kehewanan, Perikanan, dan Kelautan Kabupaten Wonogiri. 2009. Laporan Singkat Pengelolaan Usaha Perikanan di Perairan Waduk
Serbaguna Gajah Mungkur Kabupaten Wonogiri. Dinas Kehewanan, Perikanan, dan Kelautan Kabupaten Wonogiri 2009. $12 \mathrm{pp}$.

Hill, M. T. \& S. A. Hill. 1994. Fisheries Ecology and Hydropower in the Lower Mekong River: An Evaluation of Run-ofthe-River Projects. Mekong Secretariat. Bangkok. Thailand. $106 \mathrm{pp}$.

Kartamihardja, E. S., A. Krismono, C. Umar, D. H. W. Tjahjo, \& S. Nuroniah. 1988. Penelitian produktivitas Waduk Wonogiri. Laporan Tahunan Sub Balai Penelitian Perikanan Air Tawar Jatiluhur. 1-26.

Kartamihardja, E. S., Krismono, \& D. W. H. Tjahjo. 1989. Penelitian Stock Assessment Ikan di Waduk Wonogiri, Jawa Tengah. Himpunan Penelitian Perikanan Perairan Umum (Danau) Tahun 1988-1989. Sub Balai Penelitian Perikanan Air Tawar Jatiluhur. (Tidak Dipublikasikan).

Kartamihardja, E. S., K. Purnomo, \& H. Satria. 2002a. Peningkatan stok ikan patin siam (Pangasius hypopthalmus) di Waduk Wonogiri, ikan baung (Mystus nemurus) di Waduk Wadaslintang dan Udang galah (Macrobrachium rosenbergii) di Waduk Darma. Hasil Penelitian Balai Penelitian Perikanan Air Tawar Tahun 2001. 15 pp.

Kartamihardja, E. S., K. Purnomo, A. S. Sarnita, H. Satria, D. W. H. Tjahjo, \& S. E. Purnamaningtyas. 2002b. Pengkajian peningkatan stok dan pelestarian ikan patin, baung, dan udang galah di Waduk Gajahmungkur, Wadaslintang, Darma, Jatiluhur, Cirata, dan Saguling. Laporan Hasil Penelitian. Pusat Riset Perikanan Tangkap. Badan Riset Kelautan dan Perikanan. Jakarta. 
Kartamihardja, E. S. \& K. Purnomo. 2005. Keberhasilan introduksi ikan patin siam (Pangasius hypophthalmus) dan dampaknya terhadap komposisi dan hasil tangkapan ikan di Waduk Wonogiri, Jawa Tengah. Prosiding Forum Perairan Umum Indonesia I. Pemanfaatan dan Pengelolaan Perairan Umum secara Terpadu bagi Generasi Sekarang dan Mendatang. Pusat Riset Perikanan Tangkap. 321-325.

Lakra, W. S. \& A. K. Singh. 2010. Risk analysis and sustainability of Pangasianodon hypophthalmus culture in India. Genetics and Biodiversity. IX (1): 35-39.

Pomeroy, R. S., B. M. Katon, \& I. Harkes. 2001. Conditions affecting the success of fisheries co-management: Lessons from Asia. Marine Policy. 25: 197-208.

Purnomo, K. 2000. Kompetisi dan pembagian sumber daya pakan komunitas ikan di Waduk Wonogiri. Jurnal Penelitian Perikanan Indonesia. 6 (3-4): 16-23.
Purnomo, K., E. S. Kartamihardja \& S. Koeshendrajana. 2003. Pertumbuhan, mortalitas, dan kebiasaan makan ikan patin siam (Pangasius hypophthalmus) introduksi di Waduk Gajah Mungkur. Jurnal Penelitian Perikanan Indonesia: Edisi Sumber Daya dan Penangkapan. Pusat Riset Perikanan Tangkap. Badan Riset Kelautan dan Perikanan. Jakarta. 9 (3): 13-21.

Purnomo, K. \& A. Warsa. 2011. Struktur komunitas dan relung makanan ikan pasca introduksi ikan patin siam (Pangasianodon hypophthalmus) di Waduk Malahayu, Kabupaten Brebes. Jurnal Penelitian Perikanan Indonesia. 17(1): 35-44.

Rainboth, W. J. 1996. Fishes of the Cambodian Mekong. Food and Agriculture Organization Species Identification Field Guide for Fishery Purposes. Food and Agriculture Organization. Rome. 265 pp.

Suwignyo, P. 1981. Kasus Waduk Wonogiri ditinjau dari Aspek Ekologi dan Peranannya. Majalah Dwi Bulanan Pekerjaan Umum. 18 (6):24-31. 